
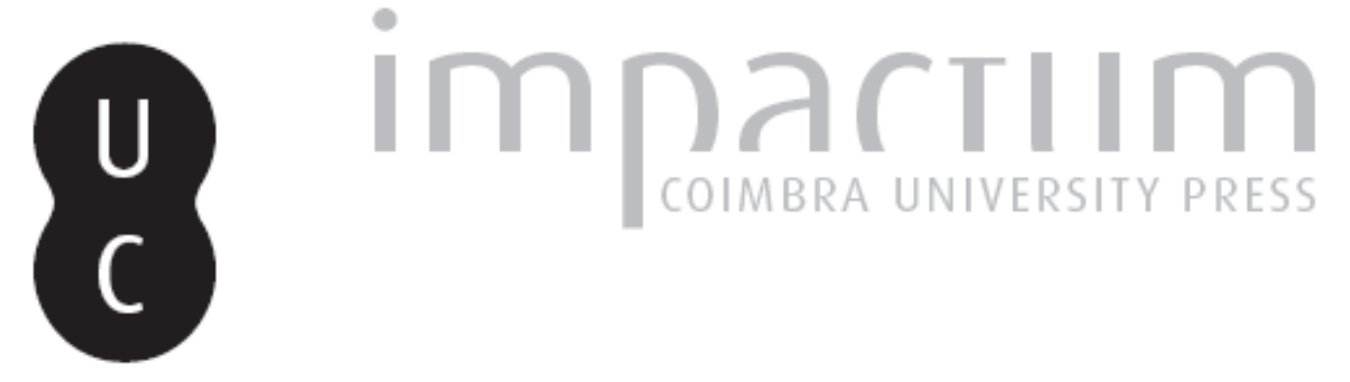

\title{
As regras dos juízos da religião em Kanti
}

\section{Autor(es): $\quad$ Conceição, Jorge Vanderlei Costa da}
Publicado por: Universidade Católica de Petrópolis; Instituto Brasileiro de Informação em Ciência e Tecnologia

URL persistente:

URI:http://hdl.handle.net/10316.2/33039

DOI:

DOI:http://dx.doi.org/10.14195/1984-6754_3-2_4

Accessed : $\quad$ 26-Apr-2023 09:41:25

A navegação consulta e descarregamento dos títulos inseridos nas Bibliotecas Digitais UC Digitalis, UC Pombalina e UC Impactum, pressupõem a aceitação plena e sem reservas dos Termos e Condições de Uso destas Bibliotecas Digitais, disponíveis em https://digitalis.uc.pt/pt-pt/termos.

Conforme exposto nos referidos Termos e Condições de Uso, o descarregamento de títulos de acesso restrito requer uma licença válida de autorização devendo o utilizador aceder ao(s) documento(s) a partir de um endereço de IP da instituição detentora da supramencionada licença.

Ao utilizador é apenas permitido o descarregamento para uso pessoal, pelo que o emprego do(s) título(s) descarregado(s) para outro fim, designadamente comercial, carece de autorização do respetivo autor ou editor da obra.

Na medida em que todas as obras da UC Digitalis se encontram protegidas pelo Código do Direito de Autor e Direitos Conexos e demais legislação aplicável, toda a cópia, parcial ou total, deste documento, nos casos em que é legalmente admitida, deverá conter ou fazer-se acompanhar por este aviso.

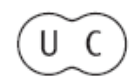



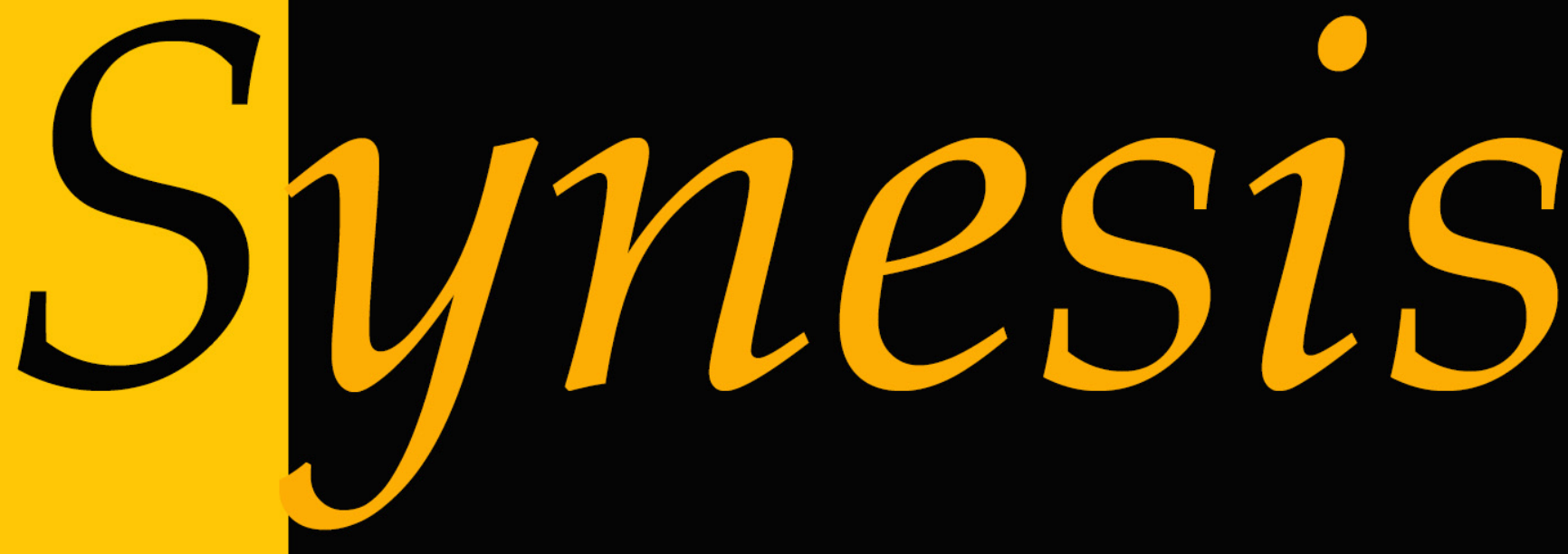

Revista do Centro de Teologia e Humanidades ISSN 1984-6754

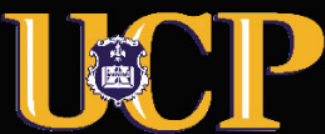




\title{
AS REGRAS DOS JUÍZOS DA RELIGIÁO EM KANT ${ }^{1}$
}

\author{
Jorge Vanderlei Costa da Conceição ${ }^{2}$
}

Resumo: Na $R G V$, Kant define a ideia da existência de Deus como o legislador moral dos seres racionais finitos. Ele na razão prática significa o legislador moral e na razáo teórica o ser absolutamente necessário ou o criador sábio da natureza. O problema é definir se os juízos da religião são os juízos da fé. Defende-se a tese que os juízos da religião na filosofia transcendental são os juízos da fé. Logo, afirmar a existência de Deus é afirmar uma condição que dá validade para um efeito (condicionado).

Palavras-chaves: Fé; Juízo condicional; Deus; Esquematismo analógico; Legislador moral.

Abstract: In the $R G V$, Kant defines the idea of the existence of God as the moral legislator of finite rational beings. God in practical reason means the moral legislator and in the theoretical reason the being absolutely necessary or the wise creator of nature. The problem is to define if the judgments of religion are the judgments of faith. It defends the thesis that the judgments in transcendental philosophy of religion are judgments of faith. Therefore, to affirm the existence of God is to affirm a condition that gives validity to an effect (conditioning).

Keywords: Faith; Conditional judgment; God; Schematic analogical; moral legislator.

\footnotetext{
${ }^{1}$ Artigo recebido em 21/04/2011 e aprovado para publicaçăo pelo Conselho Editorial em 02/12/2011.

2 Mestre em Filosofia pela Pontifícia Universidade Católica do Paraná - PUCPR. Currículo Lattes: http://lattes.cnpq.br/9993254365673186. Email: anedotismo@yahoo.com.br.
} 


\section{Introduçáo}

Referente ao juízo da fé, Kant fez a seguinte advertência na $K r V$ :

No uso transcendental da razão, pelo contrário, a opinião é, de certo, pouco demais, a ciência, porém, demasiada. Não podemos aqui de forma alguma julgar, do ponto de vista simplesmente especulativo, porque os fundamentos subjetivos da crença, como aqueles que podem produzir a fé, não merecem crédito algum nas questôes especulativas, visto não se poderem manter livres de toda a assistência empírica, nem comunicar-se aos outros no mesmo grau $(K r V, \mathrm{~A}, 823 \text { / B, 851) })^{3}$.

$\mathrm{Na} K r V$, a fé (Glaube) está contida na validade subjetiva dos juízos que Kant chama de crença (Fürwahrhaltens). Ele definiu a crença (Cf. $\mathrm{KrV}$ A820 B848) ${ }^{4}$ como o fato do entendimento que repousa sobre princípios objetivos, mas que exige causas subjetivas. Por um lado, a crença é válida para todo ser racional, quando o seu princípio é objetivamente válido, deste modo, ela se chama conviç̧ão (Überzeugung). Por outro lado, quando a crença tem o seu princípio subjetivo somente na natureza particular do sujeito, ela é chamada de persuasão (Überredung). A persuasão é uma simples aparência, porque o princípio que reside no sujeito subjetivamente não pode ser considerado objetivamente, deste modo, para Kant na persuasão pode haver uma confusão entre os princípios internos e externos na formulação do juízo.

A estrutura lógica do juízo da crença, tanto na convicção (Überzeugung) quanto na persuasão (Überredung), é a figura silogística condicional. Ambos os juízos da crença têm causas (condiçóes) subjetivas, a diferença entre eles é que no juízo da persuasão o condicionado também é subjetivo, isto é, carente de uma prova objetiva. Em contrapartida ao juízo da persuasão, no juízo da conviç̧ão o condicionado está fundamentado numa prova objetiva. Entende-se por prova objetiva a existência de um dado objetivo tanto da ordem teórica quanto da ordem prática. A tentativa de explicar causas internas como externas é chamada, por Kant,

3 Im transzendentalen Gebrauche der Vernunft ist dagegen Meinen freilich zu wenig, aber Wissen auch zu viel. In bloß spekulativer Absicht können wir also hier gar nicht urteilen; weil subjektive Gründe des Fürwahrhaltens, wie die, so das Glauben bewirken können, bei spekulativen Fragen keinen Beifall verdienen, da sie sich frei von aller empirischen [690] Beihülfe nicht halten, noch in gleichem Maße andern mitteilen lassen.

4 Das Fürwahrhalten ist eine Begebenheit in unserem Verstande, die auf objektiven Gründen beruhen mag, aber auch subjective Ursachen im Gemüte dessen, der da urteilt, erfordert. Wenn es für jedermann gültig ist, sofern er nur Vernunft hat, so ist der Grund desselben objektiv hinreichend, und das Fürwahrhalten heist alsdann Überzeugung. Hat es nur in der besonderen Beschaffenheit des Subjekts seinen Grund, so wird es Überredung genannt. Überredung ist ein blosser Schein, weil der Grund des Urteils, welcher lediglich im Subjekte liegt, für objektiv gehalten wird. Daher hat ein solches Urteil auch nur Privatgültigkeit, und das Fürwahrhalten lässt sich nicht mitteilen. 
de crença enganosa (trügliche Fürwahrhalten). De acordo com Kant, os juízos da crença estáo fundamentados numa causa subjetiva da nossa natureza (subjektive Ursache des Scheins) e são resultados do próprio funcionamento da razão (Cf. $K r V$, A, 821 / B, 849). Noutras palavras, os juízos da crença não podem ser suprimidos da razão, pois eles fazem parte do seu próprio funcionamento, mas podem ser corrigidos os seus erros.

\section{Os juízos da fé}

No início da dialética transcendental, Kant afirma existir três tipos de aparências: a aparência empírica, a aparência lógica e a aparência transcendental. Além disso, também afirma que a "verdade ou a aparência não estão no objeto, na medida em que é intuído, mas no juízo sobre ele, na medida em que é pensado" $(K r V, \mathrm{~B}, 350) .{ }^{5}$ A aparência empírica refere-se às ilusóes de ótica, neste tipo de ilusáo a faculdade de julgar é desviada pela influência da imaginação. Por exemplo, ao colocar um bastáo na água, ele aparece quebrado. Este tipo de ilusão é facilmente corrigível pelo conhecimento que temos do objeto, ou seja, sabemos que é uma ilusão de ótica, devido à água refletir a imagem do bastão como se ele estivesse quebrado.

A aparência lógica é o resultado da falta de atenção na aplicação da regra lógica. $\mathrm{O}$ exemplo da aparência lógica é o paralogismo. O paralogismo é a materialização de um conceito puro, isto é, o ser racional finito ao julgar considera um conceito como se ele fosse oriundo da sensibilidade. Neste tipo de aparência, há um erro sub-reptício. Por exemplo, a alma é o objeto de investigação da psicologia racional, introduzir um elemento empírico na psicologia racional é transformá-la numa psicologia empírica. A alma, enquanto objeto do sentido interno, náo pode ser investigada como objeto do sentido externo, cometer este erro é considerar as categorias do entendimento como oriundas da sensibilidade. Segundo Kant, não posso ter a mínima representação de um ser pensante por experiência externa, mas só pela experiência interna (Cf. $K r V, \mathrm{~B}, 405$ / A, 347). Na edição $A$ da primeira Crítica, Kant argumenta que o eu pensante não é objeto de todos os meus juízos possíveis internamente e qualquer tentativa de

5Denn Wahrheit oder Schein sind nicht im Gegenstande, so fern er angeschaut wird, sondern im Urteile über denselben, so fern er gedacht wird. 
utilizá-lo como predicado de qualquer outra coisa externa é materializar um conceito intelectual (Cf. $K r V$, A, 349).

A aparência transcendental é a miragem causada pela extensão dos conceitos puros do entendimento ao ilimitado. Para Kant, o uso dos conceitos puros do entendimento pode ser dividido em dois grupos, a saber, os imanentes e os transcendentes. Estes transpóem as fronteiras da experiência possível, enquanto aqueles ficam restritos aos limites da experiência possível. Kant distinguiu os conceitos transcendentes dos conceitos transcendentais, o primeiro, como já acima dito, se dirige para aquilo que está além da experiência; já o segundo, faz referência para princípios subjetivos que são tomados como objetivos.

Diferente da aparência lógica, a aparência transcendental náo pode ser desfeita, pois ela faz parte do próprio funcionamento da faculdade de julgar. $\mathrm{O}$ exemplo duma aparência transcendental é: o mundo tem de ter um começo no tempo. Neste juízo há uma ilusão inevitável, ou seja, a necessidade de considerar um princípio subjetivo como objetivamente válido, para pensar o começo do mundo no tempo é necessário pensar uma causa subjetiva. Em linhas gerais, a solução para a ilusão causada pela aparência transcendental é considerar os princípios subjetivos como a condição da totalidade das condiçóes, ou seja, o incondicionado na síntese das condiçóes. Mas com a seguinte advertência: considerar um incondicionado como síntese para as condiçóes não é asseverar a existência do incondicionado, mas apenas evitar a petição de princípio ao infinito da razão.

$\mathrm{Na} K r V$, o juízo da fé é classificado como um tipo de aparência, pois se fundamenta em princípios subjetivos que podem ser considerados objetivamente válidos. Referente à fé, Kant argumenta:

em caso algum, a não ser do ponto de vista prático, pode a crença teoricamente insuficiente ser chamada fé. Ora, este ponto de vista prático é ou a habilidade ou a moralidade. A primeira se refere a fins arbitrários e contingentes, a segunda, a fins absolutamente necessários $\left(K r V, \mathrm{~A}, 823\right.$ / B, 851) ${ }^{6}$.

Os juízos da fé para a filosofia especulativa não tem valor nenhum, logo, não podemos compará-los com os juízos oriundos da aparência transcendental. A aparência transcendental é o

6 Es kann aber überall bloß in praktischer Beziehung das theoretisch unzureichende Fürwahrhalten Glauben genannt werden. Diese praktische Absicht ist nun entweder die der Geschicklichkeit, oder der Sittlichkeit, die erste zu beliebigen und zufälligen, die zweite aber zu schlechthin notwendigen Zwecken. 
fundamento da possibilidade do pensar, enquanto a aparência dos juízos de fé é o mero mecanismo para justificar uma crença, que em particular refere-se apenas àquele caso específico. A fim de evitar o fanatismo religioso, Kant afirma que o juízo da fé só tem validade no domínio da filosofia prática. Na $K r V$, há três tipos de juízos: da fé de habilidade, da fé moral e da fé doutrinal.

2.1. O juízo da fé de habilidade (geschicklichkeit Glauben): uma hipótese dedutiva

O primeiro tipo de juízo de fé do ponto vista prático da habilidade refere-se a fins arbitrários. Para exemplificar os juízos da fé de habilidades Kant escreve:

Um médico deve fazer alguma coisa por um doente em perigo, mas não conhece a doença. Examina os fenômenos e julga, por não saber melhor, que é uma tísica. A sua fé, mesmo seguindo o seu próprio juízo, é simplesmente contingente; um outro poderia talvez encontrar melhor. Uma fé contingente deste gênero, mas que serve de fundamento ao emprego real dos meios para certas açóes é denominado por mim fé pragmática $(K r V \mathrm{~A}, 824 / \mathrm{B}, 852)^{7}$.

Kant também chama os juizos da fé de habilidade de juizos de fé pragmática (pragmatischen Glauben). Por exemplo, o médico ao tratar uma doença a qual não conhece, procura solucionar o problema por intermédio de hipóteses. Todo juízo hipotético é fundamentado numa causa subjetiva e sua validade lógica está na relação de conseqüência entre a condição (a hipótese) que sempre é subjetiva e o resultado (o condicional) que é o efeito objetivado pelo presente juízo (proposiçóes antecedente e consequente).

O médico opera um juízo hipotético dedutivo, que se baseia em leis, princípios e efeitos anteriormente conhecidos, que neste caso específico são os sintomas da doença. Como exemplo, Alexander Fleming ${ }^{8}$, bacteriologista do St. Mary's Hospital de Londres, fazia investigaçóes sobre substâncias capazes de matar ou impedir o crescimento de bactérias nas

7 Der Arzt muß bei einem Kranken, der in Gefahr ist, etwas tun, kennt aber die Krankheit nicht. Er sieht auf die Erscheinungen, und urteilt, weil er nichts Besseres weiß, es sei die Schwindsucht. Sein Glaube ist selbst in seinem eigenen Urteile bloß zufällig, ein anderer möchte es vielleicht besser treffen. Ich nenne dergleichen zufälligen Glauben, der aber dem wirklichen Gebrauche der Mittel zu gewissen Handlungen zum Grunde liegt, den pragmatischen Glauben.

8 Alexander Fleming foi o cientista que descobriu a penicilina. A descoberta aconteceu em 1928, enquanto o pesquisador trabalhava num hospital de Londres, na Inglaterra, em busca de uma substância que pudesse ser usada no combate a infecçóes bacterianas (causadas por bactérias). 
feridas infectadas. Num acidente ou não, não vamos discutir o mérito da questáo, identificou um fungo pertencente ao gênero Pinicilium. Deste fungo ele criou o antibiótico chamado de penicilina que é utilizado para tratar infecçóes bacteriológicas em ferimentos. Fleming tinha a crença subjetiva que poderia impedir a proliferação de bactérias em feridas. Por intermédio de diversas hipóteses, algumas das quais falseadas, ele chegou ao antibiótico que solucionava o problema.

O juizo de habilidade opera com uma suposição provisória de uma crença à espera de uma confirmação. Ao acontecer a confirmação da suposição problematizada pelo juízo da habilidade, a crença torna-se uma conviç̧ão (Überzeugung), devido haver dados objetivos que confirmam a suposiçáo (o princípio subjetivo do juízo).

\subsection{Juízo da fé doutrinal (doktrinalen Glauben): uma hipótese teórica}

O segundo tipo de juízo da fé é o doutrinal. O objeto de investigação da fé doutrinal é a hipótese transcendental da existência de Deus. Segundo Kant, "em sentido estrito, esta fé (doktrinalen Glauben) não é, porém, prática, mas deve ser chamada de fé doutrinal, que a teologia da natureza (Physikotheologie) deve necessariamente produzir por toda a parte" ( $\mathrm{Kr} V$, A, 827 / B 855). ${ }^{9}$ A doutrina da existência de Deus pertencente à fé doutrinal, está fundada em princípios subjetivos, que não podem ser considerados objetivos. A vantagem da fé doutrinal é a possibilidade de admitir uma possível unidade final para a natureza, como um fim escrito pelo seu criador sábio. $\mathrm{O}$ estatuto da hipótese da fé doutrinal pode ser classificado como teórico, que basicamente pretende agrupar a totalidade dos fenômenos sobre a regência de uma causa comum. A causa comum é a pressuposição de um Deus como a inteligência suprema e criadora, que, por sua vez, é Criador do mundo.

A desvantagem da fé doutrinal é que ela apresenta uma ambiguidade, apesar de Kant afirmar que podemos ajuizar a natureza segundo fins, sem a pressuposição de Deus. A ideia da existência de Deus é uma ideia subjetiva que possibilita pensar um início no tempo e um lugar

9 [...] aber alsdenn ist dieser Glaube in strenger Bedeutung dennoch nicht praktisch, sondern muß ein doktrinaler Glaube genannt werden, den die Theologie der Natur (Physikotheologie) notwendig allerwärts bewirken muß. 
no espaço para o surgimento do mundo sem necessariamente ter que pensar numa causa temporal e espacial para a sua criação. Diferente dos juízos de fé pragmáticos, os juízos da fé doutrinal náo podem ser comprovados por dados objetivos, apenas por uma necessidade lógica. A hipótese teórica somente pode gerar a persuasão (Überredung) e nunca a convicção (Überzeugung), por náo poder ser ligada a dados objetivos, mas apenas subjetivos. A validade da fé doutrinal é lógica, por isso, apenas uma hipótese teórica.

\subsection{Juízo da fé moral (moralischen Glauben): uma hipótese moral}

O terceiro tipo de juízo de fé é a moral, ele também está articulado na forma de um juízo hipotético. Na fé moral diferente da fé doutrinal ou da fé pragmática, o fim objetivado é considerado necessariamente válido. O fim visado pela fé moral é absolutamente necessário devido à necessidade do ser racional finito obedecer, em todos os pontos, à lei moral (Cf. $K r V$, A, 828 / B, 856). Assim, o meio e o fim objetivado na fé moral é a lei moral. Porém, o juízo de fé determina a vontade moralmente mediada pelas imagens religiosas. Deste modo, também podemos afirmar que na $K r V$ os juízos da fé moral (moralischen Glauben) são considerados preceitos morais. "O preceito moral é ao mesmo tempo a minha máxima como a razão ordena, assim acreditarei infalivelmente na existência de Deus e numa vida futura e estou seguro de que nada pode tornar a fé vacilante" $(K r V, \mathrm{~A}, 826 / \mathrm{B}, 856)^{10}$. Na $F M C$, a máxima é definida como o princípio subjetivo do querer. A pressuposiçáo da existência de Deus e da imortalidade da alma, na perspectiva kantiana, possibilita pensar a unidade final da açáo moral. Contudo, Kant adverte na $K r V$ :

\footnotetext{
ninguém se poderá gabar de saber que há um Deus e uma vida futura, pois se o soubesse seria precisamente o homem que desde há muito tempo procuro. Todo o saber (quando diz respeito a um objeto simples da razáo) pode comunicar-se e, portanto, pelos seus ensinamentos, poderia também esperar ver a minha ciência maravilhosamente ampliada. Mas não, a convicçâo não é certeza lógica (logische Gewißheit), é certeza moral (moralische Gewißheit) e, como repousa sobre princípios subjetivos (sentimento moral), não devo dizer nunca: é moralmente certo que há um
}

$10 \mathrm{Da}$ aber also die sittliche Vorschrift zugleich meine Maxime ist (wie denn die Vernunft gebietet, daß sie es sein soll), so werde ich unausbleiblich ein Dasein Gottes und ein künftiges Leben glauben, und bin sicher, daß diesen Glauben nichts wankend machen könne [...]. 
Deus, etc., mas estou moralmente certo, etc. $(K r V, \mathrm{~A}, 829 / \mathrm{B}, 857)^{11}$.

De acordo com Kant, o juízo da fé não gera certeza lógica (logische Gewißheit) e nem possui valor para a filosofia especulativa, ele apenas gera certeza moral (moralische Gewißheit). Para a certeza moral ser válida é necessário um princípio objetivo, que neste caso é a lei moral. Kant assevera que o juízo da fé se fundamenta no sentimento moral (der moralischen Gesinnung) e, por isso, gera uma convicção da ordem moral. Kant na $\mathrm{KrV}$, chama o sentimento moral de princípio subjetivo, contudo, em tal obra não é encontrada uma definição de sentimento moral. Encontramos uma possível definição de sentimento moral antes da publicação da primeira edição da $K r V$, na $\ddot{U} G T P$ como o fundamento primeiro e interno do poder de desejar e, porventura, o princípio material indemonstrável da moral (Cf. ÜGTP, AA, II, 300 / II, 301).

Continuando no texto pré-crítico, ÜGTP, a ideia da existência de Deus também é um princípio material indemonstrável da obrigação moral. $\mathrm{Na} K r V$, a certeza moral está fundamentada no sentimento moral e a justificativa kantiana é:

a única dificuldade que se apresenta aqui é que esta fé racional se funda no pressuposto de sentimentos morais. Se o pusermos de lado e admitirmos alguém que seja completamente indiferente às leis morais, a questão levantada pela razão tornase simplesmente um problema para a especulação e pode, sem dúvida, apoiar-se em fortes razóes às quais deva render-se a dúvida mais obstinada $\left(K r V\right.$ A830 B858) ${ }^{12}$.

Isto significa que não há nenhum homem isento de interesses morais, pois, na perspectiva kantiana, há um interesse natural indemonstrável pela moralidade na natureza humana. Para determinar o significado da ideia de Deus é necessária a sua vinculação ao

11 Zwar wird freilich sich niemand rühmen können: er wisse, daß ein Gott und daß ein künftig Leben sei; denn, wenn er das weiß, so ist er gerade der Mann, den ich längst gesucht habe. Alles Wissen (wenn es einen Gegenstand der bloßen Vernunft betrifft) kann man mitteilen, und ich würde also auch hoffen können, durch seine Belehrung mein Wissen in so bewundrungswürdigem Maße ausgedehnt zu sehen. Nein, die Überzeugung ist nicht logische, sondern moralische Gewißheit, und, da sie auf subjektiven Gründen (der moralischen Gesinnung) beruht, so muß ich nicht einmal sagen: es ist moralisch gewiß, daß ein Gott sei etc., sondern, ich bin moralisch gewiß etc.

12 Das einzige Bedenkliche, das sich hiebei findet, ist, daß sich dieser Vernunftglaube auf die Voraussetzung moralischer Gesinnungen gründet. Gehn wir davon ab, und nehmen einen, der in Ansehung sittlicher Gesetze gänzlich gleichgültig wäre, so wird die Frage, welche die Vernunft aufwirft, bloß eine Aufgabe für die Spekulation, und kann alsdenn zwar noch mit starken Gründen aus der Analogie, aber nicht mit solchen, denen sich die hartnäckigste Zweifelsucht ergeben müßte, unterstützt werden. 
sentimento moral, pois a ideia da existência de Deus é derivada analiticamente da ideia da lei moral. Em tal caso, é necessário postular o sentimento moral como ponto de partida das máximas morais ou apresentá-lo como hipótese da moralidade do mesmo modo que a ideia de Deus e da imortalidade da alma. De acordo com o raciocínio kantiano, na $K r V$, o ser racional finito apenas pode afirmar: (a) estou moralmente certo que há um Deus, mas não pode dizer $(b) e ́$ moralmente certo que há um Deus. Ambas as proposiçóes são fundamentadas em princípios subjetivos, a diferença entre a proposição " $a$ " e a proposição " $b$ " é que: nesta a convicção está fundamentada na certeza moral, enquanto naquela está fundamentada apenas na certeza lógica. A certeza lógica da existência de Deus não é suficiente para determinar a vontade do ser racional finito, porque o princípio determinante é subjetivo e o único princípio objetivo que determina a vontade é a lei moral.

Para demonstrar a validade da certeza moral da existência de Deus na $K r V$ é preciso evidenciar qual é o significado da proposição: estou certo moralmente que há um Deus (es ist moralisch gewi $\beta$, daß ein Gott). Para determinar o significado da presente proposição, proponho transformá-la no seguinte juízo hipotético: Se existe um sentimento moral, então estou certo moralmente que há um Deus. O sentimento moral funda o pressuposto da existência de Deus, assim, Deus não é representado na sua forma ontológica, mas como um ser moral. $\mathrm{Na} K r \mathrm{~V}$, a fé em Deus ou a crença na existência da imortalidade da alma estáo interligadas ao sentimento moral, ou seja, tanto o sentimento moral quanto a hipótese transcendental da existência moral de Deus geram um conteúdo para a forma da lei. A lei ordena formalmente a adoção de máxima de virtude como fundamento determinante da vontade, a fé gera um tipo de conteúdo material para as máximas morais. Defendo a tese que a representação da existência moral de Deus é como o ser racional finito o imagina como ser moral. Kant afirma na $K r V$, que os juízos da crença são juízos hipotéticos. O presente capítulo defende a tese que, na primeira Crítica, a ideia da existência de Deus é uma hipótese moral, porque o sentimento serve como condição para a sua existência. Logo, na $K r V$ os juízos da fé são juízos hipotéticos, que apenas servem de preceitos morais subjetivos e que necessitam de uma validade objetiva. A validade objetiva do juízo da fé é a lei moral, mas o fundamento do juízo é subjetivo é a certeza moral da existência de Deus.

Portanto, a certeza moral da existência de Deus é a sua representaçáo vinculada ao 
sentimento moral. Dito de outro modo, não é a determinação da natureza divina (os seus predicados ontológicos) como na fé doutrinal, mas o que Deus significa para o ser racional finito como ser moral que ordena a realizaçáo da lei. A ideia da existência de Deus é uma hipótese, pois é necessário pressupor a sua existência, da mesma maneira que é indispensável conjecturar a existência do sentimento moral. Mas o seu significado é determinado na relação da vontade do ser racional e a lei moral, qualquer representação contrária da existência de Deus à lei moral é uma contradição interna de termos.

\subsection{Os juízos da fé na $K p V$}

$\mathrm{Na}$ introdução da $K p V$, Kant afirma:

Ora, aqui se encontra, em comparação com a razão especulativa, um fundamento meramente subjetivo do assentimento, que, todavia, é objetivamente válido para uma razão igualmente pura mas prática, como o que e mediante o conceito de liberdade é proporcionado realidade objetiva às ideias de Deus e de imortalidade da alma <é proporcionada> a faculdade, antes, a necessidade subjetiva (carência da razão pura) de admiti-las, sem que com isso, todavia, a razão seja ampliada no conhecimento teórico, mas que apenas a possibilidade, que antes não passava de problema e aqui se torna asserção, seja dada, e assim o uso prático da razão é conectado com os elementos do uso teórico. E esta carência não é, por assim dizer, uma necessidade hipotética de um objetivo qualquer da especulação - de que se tenha de admitir algo dado se queira elevar-se à completude do uso da razão na especulação - mas é uma necessidade legal de admitir algo, sem a qual não pode ocorrer o que se deve pôr incessantemente como objetivo de sua conduta ( $K p V$, AA, 05$, p. 7$)^{13}$.

Kant argumenta que a ideia da existência de Deus para a razão especulativa é meramente um princípio subjetivo e para a razão prática é objetivamente válido. Deste modo, a existência de Deus, que para a razão teórica era uma hipótese moral, passa a ser um postulado na razão prática. $\mathrm{Na}$ razão teórica a ideia da existência de Deus é fundamentada numa hipótese

13 Hier ist nun ein, in Vergleichung mit der spekulativen Vernunft, bloß subjektiver Grund des Fürwahrhaltens, der doch einer eben so reinen, aber praktischen Vernunft objektiv gültig ist, dadurch den Ideen von Gott und Unsterblichkeit vermittelst des Begriffs der Freiheit objektive Realität und Befugnis, ja subjektive Notwendigkeit (Bedürfnis der reinen Vernunft) sie anzunehmen verschafft wird, ohne daß dadurch doch die Vernunft im theoretischen Erkenntnisse erweitert, sondern nur die Möglichkeit, die vorher nur Problem war, hier Assertion wird, gegeben, und so der praktische Gebrauch der Vernunft mit den Elementen des theoretischen verknüpft wird. Und dieses Bedürfnis ist nicht etwa ein hypothetisches, einer beliebigen Absicht der Spekulation, daß man etwas annehmen müsse, wenn man zur Vollendung des Vernunftgebrauchs in der Spekulation hinaufsteigen will, sondern ein gesetzliches, etwas anzunehmen, ohne welches nicht geschehen kann, was man sich zur Absicht seines Tuns und Lassens unnachlaßlich setzen soll. 
moral, na razão prática, particularmente na $K p V$, é fundamentada num postulado. Qual é a diferença entre a hipótese e o postulado? O postulado é uma proposição não absolutamente evidente nem indemonstrável, mas é uma verdade legítima. A transformação de hipótese em postulado conduz à presente indagação: qual é o estatuto do postulado da existência de Deus e a estrutura do juízo da fé na $K p V$ ? Para compreender a estrutura lógica dos juízos da fé, na segunda Crítica, é necessário caracterizar a função do postulado da existência de Deus como a possibilidade da condiçáo de um objeto de uma vontade moralmente boa determinada a priori.

\section{A estrutura do juízo da fé na $K p V$}

Para descrever o problema da fé na $K p V$, Kant escreve: "deveria quase parecer que esta fé racional (Vernunftglaube), ela mesma anunciada aqui como mandamento, a saber, de admitir o sumo bem como possível" (KpV, AA, 05, 260) ${ }^{14}$. A presente passagem apresenta o seguinte problema: que tipo de mandamento a fé racional anuncia? Vimos que na $K r V$, o juízo da fé é fundamentado em princípios subjetivos e sua validade é dada pelo sentimento moral. Proponho interpretar o juízo da fé na primeira Crítica por intermédio do juízo condicional: Se existe um sentimento moral, então estou certo moralmente que há um Deus. Na segunda Crítica, a fé racional (Vernunftglaube), que é sinônimo de fé moral (moralischen Glauben), anuncia um mandamento que é a admissão do sumo bem (höchste Gut). A exemplo da $K r V$, proponho formular o juízo da fé, na $K p V$, na forma de um silogismo condicional: se há um Deus, por conseguinte, há um sumo bem no mundo. A formulação do juízo da fé na forma de um juízo condicional na primeira Crítica é o sustentáculo para evidenciar a ligação da ideia da existência de Deus e o sumo bem.

$\mathrm{Na} K p V$, o juízo da fé anuncia um mandamento, este é a promoção e a admissão do sumo bem como algo realizável pelos seres racionais finitos. Mas, "ao mesmo tempo enquanto meio de promoção daquilo que é objetivamente (praticamente) necessário, o fundamento de uma máxima do assentimento de ponto de vista moral, isto é, uma fé racional prática pura”

14 Es sollte fast scheinen, als ob dieser Vernunftglaube hier selbst als Gebot angekündigt werde, nämlich das höchste Gut für möglich anzunehmen. 
$(K p V, \mathrm{AA}, 05,263)^{15}$. Deste modo, a pergunta: que tipo de mandamento a fé racional anuncia, transmuta na respectiva questão: qual é a importância da doutrina do sumo bem na determinação da vontade do ser racional finito?

\subsection{A doutrina do sumo bem: o mandamento da fé}

Para Beck (Cf. 1960, p. 245), a doutrina do sumo bem objetiva solucionar a dialética da razão prática. Ainda de acordo com Beck, a doutrina do sumo bem não faz referência para a determinação da vontade do ser racional finito, mas é um problema da razão na sistematização das soluçóes de suas inquiriçóes. Podemos inferir da argumentação de Beck (Cf. 1960, p. 245) que a problemática da doutrina do sumo bem está vinculada a questão da arquitetônica da razão e nâo ligado diretamente à determinação da vontade do ser racional finito. Allison (Cf. 1990, p. 174) defende a tese que a doutrina do sumo bem é essencial para a filosofia prática, devido à introdução do postulado da imortalidade da alma e do postulado da existência de Deus. Allison argumenta: "o problema da conexão do postulado da imortalidade, que, juntamente com o da existência de Deus (e liberdade), é postulado como uma condição necessária para a realização do sumo bem" ${ }^{16}$. Isto significa que, a doutrina do sumo bem possibilita ao ser racional finito pensar na sua vontade determinada independente dos objetos sensíveis. Assim, a virtude torna-se causa da felicidade, considerando a seguinte advertência: somente a lei moral determina incondicionalmente a vontade do ser racional finito.

Diferente de Beck (Cf. 1960, p. 245) e Allison (Cf. 1990, p. 174), Henrich (Cf. 2003, p. 28) afirma:

creio que Kant foi realmente imprudente quando, sem hesitação, ele identificou a ordem moral do sumo bem e o reino da graça. Mas isso não implica que a noção de uma ordem moral pode ser dispensada ou que é desprovido de conteúdo. Além disso, ao contrário de Kant, é preciso distinguir entre vários tipos de conduta moral e estágios no âmbito do desenvolvimento da consciência moral do homem. Isso

15 so ist das Prinzip, was unser Urteil hierin bestimmt, zwar subjektiv, als Bedürfnis, aber auch zugleich als Beförderungsmittel dessen, was objektiv (praktisch) notwendig ist, der Grund einer Maxime des Fürwahrhaltens in moralischer Absicht, d.i. ein reiner praktischer Vernunftglaube.

16 [...] the problem in conection with the account of immortality, which, together with the existence of God (and freedom), is postulated as a necessary condition of the realization of the Highest Good (ALLISON, H. 1990. p.172). 
acrescenta outra dimensão ao conceito da imagem moral do mundo ${ }^{17}$.

De acordo com o Henrich, Kant foi imprudente ao relacionar o sumo bem ao reino da graça, por náo distinguir entre os vários tipos de conduta moral. Henrich (Cf. 2003, p. 28) sugere que a determinação da vontade do ser racional finito pode ser determinada pelo sumo bem no âmbito da estética, do direito e da religiáo. Assim, o sumo bem pode ser identificado com outros objetos da razão prática e, não necessariamente, com o Reino de Deus. Dito de outro modo, Deus pode ordenar ao ser racional finito realizar o sumo bem, mas não é o único objeto da razão prática que ordena tal mandamento.

Tanto para Henrich (Cf. 1993, p. 28) quanto para Allison (Cf. 1990, p. 174), a doutrina do sumo bem objetiva solucionar o problema de como o homem pode se tornar digno da felicidade, ou seja, demonstrar que a virtude pode ser a causa da felicidade. Diferente de Allison (Cf. 1990, p.174), Henrich (Cf. 1993, p. 28) argumenta que outras ideias da razão podem ocupar o lugar da ideia da existência de Deus como a condiçáo para a existência do sumo bem. Defendendo uma posição mais radical, Beck (Cf. 1960 p.245) argumenta que o sumo bem é um problema da dialética da razão prática e náo algo essencial para a moral kantiana, isto é, um objeto para se pensar uma vontade determinada segundo fins.

A interpretação de Henrich (Cf. 1993, p. 28) pode ser alinhada com a de Ostaric (Cf. 2009, p. 669), ela assevera, tendo como base a $K U$ : "a moral traz promessas subjetivas de que vão persistir na atitude moral, se o ideal do sumo bem é livremente aprovado pela [ela] razão"18. Ostaric relaciona a doutrina do sumo bem com a felicidade moral (moral happiness), presente na $R G V$, e a imagem moral do mundo (moral image of the World), presente na $K U$. Diferentemente dos outros comentadores, Ostaric (Cf. 2009 p. 669) dá ênfase para a importância do postulado da imortalidade da alma, como a possibilidade para pensar a felicidade moral. E o postulado da existência de Deus é a condição para pensar a felicidade como efeito da moralidade. Todavia, Ostaric (Cf. 2009, p. 665) argumenta que outros objetos

17 I believe that Kant was indeed ill-advised when, without hesitation, he identified the moral order of the highest good and the realm of Grace. But that by no means implies that the notion of a moral order can be dispensed with or that it is devoid of content. In addition, unlike Kant, we must distinguish between various kinds of moral conduct and stages within the development of the moral awareness of man. This adds yet another dimension to the notion of the moral image of the world (HENRICH, D. 1993. p.28).

18 "The moral subject gains assurance that she will persist in her moral disposition if the ideal of the highest good is "freely approved by $[\mathrm{He}]$ reason (OSTARIC, L. 2009. p.669)." 
podem ser a condição para a existência do sumo bem, assim, fazendo a mediação entre a vontade do agente moral e a lei moral.

Para efetivar a construção da imagem moral do mundo, Ostaric (Cf. 2009 p. 669) é afirmativo ao recordar que a "[...] obra de um gênio como um símbolo da moralidade ajuda a manter a disposição moral da fé, servindo, assim como uma fonte de motivação moral" ${ }^{19}$. Neste sentido, a leitura de Ostaric (Cf. 2009 p. 669) vai de encontro à leitura de Henrich (Cf. 1993 p. 28), no que se refere à doutrina do sumo bem que objetiva fazer a conexáo da vontade do ser racional finito como agente moral noumênico quanto agente moral fenomênico. Deste modo, a existência de Deus é dispensável como a condição do consequente que é o sumo bem na $K p V$ e na $R G V$, sendo substituída pela figura do gênio que está presente na $K U$. Concordo com ambos comentadores, mas com a seguinte advertência: a doutrina do sumo bem possibilita ao ser racional finito pensar a sua vontade determinada mediatamente pela lei moral ${ }^{20}$. Dentro do âmbito da filosofia, a ideia da existência de Deus náo pode ser substituída por outra, por exemplo, pela imagem moral produzida pelo gênio, como defende Ostaric (Cf. 2009. p.669). Ela náo pode ser substituída devido a sua existência ser o problema central da filosofia da religiáo.

Há um desacordo entre os comentadores no papel sine qua non da ideia da existência de Deus como a condição necessária para a admissão do sumo bem. Por exemplo, Allison (Cf. 1990, p. 174), Henrich (Cf. 1993, p. 28) e Ostaric (Cf. 2009, p. 669) argumentam que a ideia da existência de Deus não é condição necessária para o sumo bem. Como exemplo, Ostaric (Cf. 2010, p. 31-33) defende o ponto de vista que a obra do gênio serve como uma exposiçáo sensível do sumo bem. O trabalho do gênio é construir uma imagem moral do mundo que o torna hospitaleiro para os fins morais. A beleza da arte e da natureza pode simbolizar o sumo

19 "[...] work of genius as a symbol of morality helps one maintain Glaube and one's moral disposition, serving, thus, as a source of moral motivation (Cf. 2009. p.669)."

20 A doutrina do sumo bem objetiva solucionar a antinomia da razáo prática, a saber, ou o apetite de felicidade tem que ser a causa motriz de máximas da virtude, ou a máxima da virtude tem que ser a causa eficiente da felicidade (Cf. KpV AA 05 202). Na perspectiva kantiana, a máxima da virtude tem que ser a causa eficiente da felicidade e a proposição contrária é falsa. Tanto a virtude quando a felicidade são dois fins mediatos para a determinação imediata da vontade pela lei moral. Por um lado, a virtude se apresenta como um fim do mundo noumênico, que reivindica a necessidade de máximas de virtude. Por outro lado, a felicidade se apresenta como apetite de uma vontade que está presente no mundo fenomênico. A antinomia objetiva demonstrar a relação entre os motivos da realização do dever moral no mundo noumênico e fenomênico. 
bem na estética, mas não podem simbolizar na religiáo. O trabalho de Ostaric (Cf. 2009 p. 669 e 2010 p. 33) não faz a distinção entre a ideia de simbolizar e a ideia de tornar efetivo. Por um lado, simbolizar significa que analogamente a beleza pode simbolizar o sumo bem. Por outro lado, na $R G V$, a ideia da existência de Deus efetiva a ideia de sumo bem.

Perez (Cf. 2007, p. 95) defende a ideia que na $R G V$ há uma efetividade prática do sumo bem e da ideia da existência de Deus. Perez apenas aponta para a possibilidade ao relacionar o sumo bem com a ideia de Reino de Deus. Defendo a tese que a efetividade prática é a representação moral da ideia da existência de Deus como ser moral. Assim, não está em questáo definir a natureza divina, mas o que a natureza divina significa como ser moral para o ser racional finito. A efetividade prática significa que podemos ter um tipo de conhecimento prático do postulado da ideia de Deus e do sumo bem. $\mathrm{Na}$ esfera da filosofia da religiáo, o postulado da existência de Deus ordena a realizaçáo do sumo bem e não representa o sumo bem, como acontece na estética kantiana. Nos juízos da religiáo a existência do sumo bem é derivada analiticamente da ideia da existência de Deus. Enquanto na estética, a beleza da obra de arte e da natureza simboliza a ideia de sumo bem. Há uma distinção entre os juízos da religiáo e os juízos estéticos. Nestes, a beleza simboliza o sumo bem, enquanto naqueles o postulado da existência de Deus afirma existência do sumo bem como algo realizável pelo ser racional finito.

Concluindo, a doutrina do sumo bem é um objeto necessário para se pensar a vontade determinada mediatamente pela lei moral. Não é simplesmente um problema da arquitetônica da razão prática, como defende Beck (Cf. 1960, p. 245), porque sem a admissáo do sumo bem náo podemos pensar numa vontade finita determinada mediatamente pela lei moral. Deste modo, contrariando a tese de Allison (Cf. 1990, p. 174), Henrich (Cf. 1993, p. 28) e Ostaric (Cf. 2009, p. 669) que defendem que a ideia da existência de Deus não é a condição para admissáo do sumo bem, ratifico que no domínio da filosofia da religiáo o postulado da existência de Deus é a condição necessária para a admissáo do sumo bem. Destarte, o sumo bem é um objeto necessário da razão prática para pensarmos uma vontade determinada mediatamente pela lei moral. 


\subsection{O postulado da existência de Deus e o juízo da fé}

Na matemática os postulados são princípios que auxiliam na dedução matemática. Como já afirmado acima, o postulado é uma verdade indemonstrável, isto é, o princípio é a condição de toda demonstração. O postulado da existência de Deus efetiva a ideia da existência de um sumo bem realizável pelo homem. Para classificar a validade do mandamento da fé, na segunda Crítica, argumenta-se que o juízo hipotético: "se há um Deus, por conseguinte, há um sumo bem no mundo" é o mandamento da fé. Diferente da $K r V$, Deus não é tomado como hipótese moral na $K p V$, mas como um objeto que possibilita ao ser racional finito pensar na sua vontade determinada mediatamente pela lei moral.

A relação entre duas proposições num juízo condicional é caracterizada pela relação da consequência necessária entre as proposiçôes. Assim, a verdade ou a falsidade de cada sentença não é determinada isoladamente. Essa relação entre as proposições podem ser exemplificadas na tabela de verdade.

\begin{tabular}{|c|c|c|}
\hline $\mathrm{p}$ & $\mathrm{q}$ & $\mathrm{p}$ \\
\hline $\mathrm{V}$ & $\mathrm{V}$ & $\mathrm{V}$ \\
$\mathrm{V}$ & $\mathrm{F}$ & $\mathrm{F}$ \\
$\mathrm{F}$ & $\mathrm{V}$ & $\mathrm{V}$ \\
$\mathrm{F}$ & $\mathrm{F}$ & $\mathrm{V}$ \\
\hline
\end{tabular}

$\mathrm{Na}$ relação entre proposições condicionais, a fórmula do juízo é incorreta quando a proposição antecedente é verdadeira e a consequente é falsa. Se a condição for falsa e o condicionado for verdadeiro, então, o valor lógico na relação entre proposiçóes condicionais é correto. Além disso, quando o antecedente e o consequente são verdadeiros ou falsos, o valor lógico do juízo condicional é correto. No Log, Kant argumenta:

nos juízos categóricos não há nada problemático, tudo é assertivo. Nos hipotéticos, inversamente, só a consequência (die Consequenz) é assertivo. Nestes últimos, posso ligar dois juízos falsos um ao outro, pois aqui só a correção da ligação importa - forma da consequência, sobre a qual repousa a verdade lógica desses juízos ( $L O G$, AA, 09, 105) $)^{21}$. (Grifos nossos)

\footnotetext{
${ }^{21}$ In kategorischen Urteilen ist nichts problematisch, sondern alles assertorisch; in hypothetischen hingegen ist
} 
No juízo hipotético, o valor lógico está determinado pela relação de consequência entre as proposiçóes e, o único caso de falsidade do juízo é quando o antecedente é verdadeiro e o consequente falso. No juízo condicional o consequente deve ser enunciado de forma assertiva. Para determinar a falsidade e a verdade de cada proposiçáo do juízo condicional é necessário analisar o significado de cada uma. O significado da ideia de Deus é determinado pela seguinte interrogaçáo: como o ser racional finito representa o postulado da existência de Deus como ser moral? O ser racional finito representa Deus como o legislador moral, qualquer representação contrária à ideia da lei moral é considerada como falsa. Para decidir sobre a verdade ou falsidade da ideia da existência de Deus, devemos nos perguntar: aquilo o qual nós chamamos de Deus é representado como o legislador moral? Se a resposta for sim, a ideia da existência de Deus como ser moral é verdadeira. Mas, se a reposta for não, há uma confusão interna na formulaçáo do juízo, ou seja, há uma auto contradiçáo na definiçáo do significado do termo.

De acordo com Kant, é comum que o ser racional finito crie uma imagem subjetiva de Deus, mas externalizar a imagem subjetiva como objetiva pode ser uma confusão entre o princípio interno e externo na formulação do juízo. A externalizaçáo da ideia da existência de Deus somente é possível por intermédio da lei moral, que o representa como legislador moral. Se a representaçáo da ideia da existência de Deus é efetivada como legislador moral, entáo o seu mandamento é a realização do sumo bem, que significa a adoção da moralidade como causa da felicidade. Para decidir sobre a verdade das proposiçóes constituintes do juízo condicional deve-se relacioná-las com a lei moral. Se a representação de Deus ou do sumo bem for contrária à lei moral, entáo as proposiçóes são tidas como falsas. A validade do juízo condicional é determinada pela consequência entre as proposiçóes constituintes do juízo, neste caso, o consequente ordena a realização da maior perfeição moral pelo ser racional finito.

Ainda de acordo com Kant, o sumo bem é o objeto necessário de uma vontade determinável pela lei moral (Cf. KpV, AA, 05, 220). Em tal vontade, a conformidade plena das disposiçóes da lei moral equivale à condição suprema do sumo bem, isto é, o sumo bem tem que ser possível enquanto objeto de uma vontade determinada pela lei moral. A fé prática

nur die Konsequenz assertorisch. In den letztern kann ich daher zwei falsche Urteile mit einander verknüpfen; denn es kommt hier nur auf die Richtigkeit der Verknüpfung — die Form der Konsequenz an; worauf die logische Wahrheit dieser Urteile beruht. 
exprime em forma de mandamento a realização do sumo bem no mundo realizável pelo homem, pois há um Deus que ordena a sua realização. No Manual dos Cursos de Lógica Geral, Kant define os juízos práticos dizendo: as "proposiçóes que enunciam (aussagen) a ação (Handlung) como condição de um objeto (Object) e pela qual ele se torna possível” (LOG, AA, 09, 110). Quando a fé prática ordena a realização do sumo bem no mundo, sob a condição da existência de Deus, ela está enunciando um juízo prático que determina uma ação sob a condição de um objeto, que torna possível um efeito no mundo fenomênico. O sumo bem é o condicionado e o postulado da existência de Deus é a condição para se pensar o condicionado. Sem a condição não podemos enunciar uma ação possível como condição de um objeto que torna possível a açáo. $\mathrm{O}$ postulado da existência de Deus deve ser admitido para podemos admitirmos a existência do sumo bem. Portanto, o juízo da fé na $K p V$ e na $R G V$ é: se há um Deus, por conseguinte, há um sumo bem.

\subsection{O postulado da existência de Deus e a felicidade.}

De acordo com a interpretação de Rauscher, na primeira Crítica não há indícios dos postulados práticos. Kant apenas utiliza o termo postulado, que, porventura, era sinônimo de hipótese. Na $K r V$, o postulado da existência de Deus é tratado como hipótese que objetiva resolver problemas oriundos da razão prática. A existência de Deus é válida como uma hipótese moral, porque é um requerimento a posteriori duma necessidade empírica que reivindica à razão teórica um conceito transcendental. Para validar a sua tese, Rauscher recorre ao texto do período pré-crítico, a ÜGTP. Nesta obra, Kant assevera que Deus é um ideal necessário da ordem natural, mas que também pode servir como hipótese da ordem moral. Rauscher conclui que a ideia da existência de Deus serve de hipótese para as proposiçóes teóricas e para as práticas, tanto no período pré-critico quanto na primeira Crítica.

$\mathrm{Na}$ segunda Crítica, ainda de acordo coma interpretação de Rauscher (Cf. 2007 p.14), o postulado da existência de Deus é relacionado com a vontade e com a escolha, que são disposiçóes subjetivas do homem. A mudança primordial da hipótese para o postulado da existência de Deus, da primeira para a segunda Crítica, é o relacionamento da existência de Deus com a lei moral. Por um lado, na primeira Crítica, Deus é uma hipótese moral, pois serve 
como condição para a validade do sumo bem. Por outro lado, na segunda Crítica, o postulado da existência de Deus é um objeto da razão prática, que determina a vontade do ser racional finito segundo fins morais. Seguindo o raciocínio de Rauscher, pode-se inferir que a diferença entre a $K r V$ e a $K p V$ é: nesta a ideia da existência de Deus é um postulado prático, pois faz parte dos objetos da razão prática que determinam a vontade do ser racional finito mediatamente conforme a lei; enquanto, naquela a ideia da existência de Deus é uma hipótese moral que objetiva demonstrar a validade do sumo bem. A relaçáo do postulado da existência de Deus com a determinação da vontade do ser racional finito na $K p V$ efetiva-se, conforme Rauscher, na indagação do ser racional finito: se eu faço o que devo, então o que eu posso esperar? Para melhor compreender o problema alertamos para o que afirma Rauscher:

Em vez disso, a base do uso prático do conceito de "Deus" é uma pergunta diferente, "o que posso esperar". Kant coloca desta forma condicional: "Se eu fizer o que eu deveria, então o que posso esperar." Grosseiramente falando, este inverte os resultados anteriores condicional e em "o dever moral de Deus"(RAUSCHER, F, $2007,14)^{22}$.

Ainda de acordo com Rauscher, o postulado da existência de Deus procura demonstrar a validade do respectivo juízo condicional: se faço o que devo, então o que eu posso esperar? Rauscher propõe que devemos estruturar o juízo condicional do seguinte modo: "se realizo com o dever moral de Deus, então o que eu posso esperar." Para estabelecer o significado da ideia de Deus no domínio prático, ele argumenta que a transformação do juízo condicional possibilita ao ser racional finito poder pensar na existência de um legislador moral. Este legislador moral possibilita ao ser racional finito pensar na imortalidade da sua alma e na felicidade como o resultado da moralização do seu caráter. Isso quer dizer que, se o homem realizar com o dever moral de Deus, entáo, ele pode ser esperançoso de se tornar digno da felicidade. Logo, a interrogação: o que posso esperar? É respondida do seguinte modo: se eu realizar o dever moral de Deus, entáo posso esperar ser feliz no reino de Deus. De acordo com Rauscher, Deus possibilita ao ser racional finito pensar a felicidade como efeito da adoção de máxima de virtude como fundamento da ação moral, pois o ser racional finito tem uma

\footnotetext{
${ }^{22}$ Rather, the basis of the practical use of the concept "God" is in a different question, "what may I hope". Kant puts conditional this way: "If I do what I should, what then may I hope" Roughly speaking, this reverses the previous conditional and results in "If Moral duty God".
} 
imagem subjetiva de Deus. O problema é definir o significado da imagem subjetiva de Deus formada pelo ser racional finito, pois cada um cria uma imagem subjetiva para si.

Na $R G V$, segundo Rauscher (Cf. 2007 p.14), Kant sugere que a ideia da existência de Deus é construída por meio de uma tríplice qualidade moral, a saber, o legislador santo e moral (moralisch als heiligen Gesetzgeber), o governante bondoso e moral do mundo (gütigen Regierer und moralischen) e o juiz justo (gerechten Richter) dos homens. Em primeiro lugar, não se deve representar o legislador santo como clemente ou indulgente para com a fraqueza dos homens, nem como despótico e imperando apenas segundo o seu direito ilimitado. Assim, o legislador supremo não é o legislador de leis arbitrárias, ele reivindica a santidade do homem. Em segundo lugar, não se deve pôr a sua bondade numa benevolência incondicionada para com as criaturas. Mas no fato d'Ele olhar primeiro para a qualidade moral do homem, que possa agradá-lo e, só entáo, ele supre a incapacidade do homem de satisfazer por si mesmo essa condição. Em terceiro lugar, a sua justiça (o juiz justo dos homens) não pode ser representada como bondade susceptível de perdão sem a transformaçáo do móbil moral (o que encerra uma contradição).

A existência de Deus é representada pela sua tríplice qualidade moral, que não significa a denominação de personalidades diferentes para um único ser. A ideia da existência de Deus possibilita ao ser racional finito pensar na existência do governador do mundo com qualidades morais. Assim, dentre as características da religiáo racional, a primordial é definir o significado da representação moral da existência de Deus. Cada ser racional finito forma para si uma imagem de Deus, o problema é quando ela está desvinculada da representação do legislador moral. Segundo a interpretação de Rauscher (Cf. 2007 p.14), não é ruim que o ser racional finito crie uma imagem subjetiva de Deus, considerando a presente advertência: a imagem subjetiva de Deus na $R G V$ náo pode estar contrária à ideia da existência de um legislador moral (moralischen Gesetzgebers) poderoso.

Segundo Rauscher (Cf. 2007, p.16), o postulado da existência de Deus, na $K p V$, objetiva solucionar a antinomia da razão prática que apresenta o seguinte dilema: a felicidade é causa de máxima de virtude ou a máxima de virtude é causa da felicidade? Para Kant, a moralidade deve ser causa da felicidade, pois o ser racional finito tem a obrigação de se tornar digno da felicidade. O ser racional finito é destinado a se tornar digno da felicidade, que 
significa ser moral incondicionalmente, mesmo que isto implique em não ser feliz. A solução para o problema da felicidade é eleger um ser soberano que possa garantir a felicidade, caso o ser racional finito torna-se digno à ela. $\mathrm{Na} K p V$, o autor escreve:

eu dissera anteriormente que, baseado num simples curso natural do mundo, a felicidade exatamente proporcionada ao valor moral não pode ser esperada no mundo e deve ser considerada impossível e que, pois, sob este aspecto, a possibilidade do sumo bem só pode ser concedida sob a pressuposição de um Autor moral do mundo (KpVAA 05261$)^{23}$.

A existência do Autor moral do mundo (Deus) como um postulado prático, possibilita ao ser racional finito, pensar na imortalidade da sua alma, que pressupóe a probabilidade da felicidade na vida eterna. Mas, para o homem ser feliz na eternidade é necessário tornar-se digno da felicidade, que somente é atingível pela adoção da máxima de virtude.

A razão teórica apresenta uma carência no seu uso especulativo que conduz para hipóteses, ao contrário dela, a razão prática conduz para postulados na $K p V$. Na ausência de fundamento, a razão prática não precisa avançar até a especulação teórica, mas somente pressupor uma divindade. Esta divindade é um conceito sem extensão do ponto de vista teórico (um conceito vazio), mas do ponto de vista moral é o legislador moral (moralischen Gesetzgebers) poderoso, que ordena realização do sumo bem como fim último da vontade do ser racional finito. A interpretação de Rauscher (Cf. 2007 p.14) assevera que Deus é um conceito sem extensão, mas a sua funcionalidade é garantida por dois fatores ligados analiticamente: a) a reivindicação prática à razão teórica, que utiliza a idéia de Deus como o autor do mundo e legislador moral; b) a função regulativa do conceito Deus, que unifica diversos conceitos morais que náo possuem referência nenhuma, a saber, virtude e felicidade. Assim, se o homem realizar com o dever moral de Deus, entáo ele pode esperar ser feliz.

De acordo com Rauscher (Cf. 2007 p.14), na $R G V$, Deus é um conceito sem extensão, isto é, o sujeito não está incluso dentro do predicado. Por exemplo, no juízo o homem é imortal, o sujeito homem não está incluso no predicado imortal. Ele quer dizer que, a posição de Deus como sujeito num juízo, ele não vai estar incluso no predicado. Em contrapartida, na extensão

\footnotetext{
${ }^{23}$ Oben hatte ich gesagt, daß, nach einem bloßen Naturgange in der Welt, die genau dem sittlichen Werte angemessene Glückseligkeit nicht zu erwarten und für unmöglich zu halten sei, und daß also die Möglichkeit des höchsten Guts, von dieser Seite, nur unter Voraussetzung eines moralischen Welturhebers könne eingeräumt werden.
} 
do juízo, temos a compreensão, que significa que é a inclusão do predicado no sujeito. Quando dizemos: o homem é racional, percebemos que o predicado racional está incluso no sujeito homem, pois além de ser racional, ele têm outras qualidades. Sugiro que, quando Rauscher afirma que Deus é um conceito sem extensão, ele quer dizer que na posição de sujeito num juízo Ele não está incluso dentro do predicado. A posição do conceito Deus como sujeito torna o juízo sem extensão, pois o sujeito não está incluso no predicado. Se mudar a posição dele do sujeito para o predicado, temos um juízo sem compreensão, porque o predicado não estará incluso dentro do sujeito. O juízo Deus existe é sem extensão, já que o sujeito náo está incluso no predicado. Para validar a pergunta sobre a existência de Deus no projeto crítico kantiano, ele propóe transformar a hipótese transcendental e o postulado em regras práticas do como se (alsob).

A novidade apresentada por Rauscher (Cf. 2007) é o intento de evidenciar a transformação da questão: "o que devo esperar?" $\mathrm{Na}$ interrogação condicional: "se realizo com o dever moral de Deus, então o que eu posso esperar?”. Ele evidencia que a vontade do ser racional finito não é determinada puramente pela lei moral, mas, também, pelos objetos da razáo prática. Em outras palavras, o ser racional finito espera por algo que não conhece, mas acredita poder ser feliz se existir Deus e sua alma for imortal. Do ponto de vista de Rauscher, a validade da pergunta pela existência de Deus é dada pela transformação de hipótese, na $K r V$, para postulado, na $K p V$, e, deste para regras práticas do como se (als ob) na $R G V$. Isto significa que, o ser racional finito age como se (als ob) existisse um legislador moral (moralischen Gesetzgebers) que ordenasse a realizaçáo dos seus deveres morais como mandamentos divinos. Deste modo, o significado da ideia de Deus é dado pela regra prática do como se (als ob). O ser racional finito age como se existisse um legislador moral (moralischen Gesetzgebers) poderoso (Deus) que, por sua vez, é o legislador santo e moral (moralisch als heiligen Gesetzgeber), o governante bondoso e moral (gütigen Regierer und moralischen) e juiz reto (gerechten Richter) dos homens.

\subsection{Os juízos da fé na $R G V$}

Segundo Kant, na $R G V$, é necessário que todos os homens criem para si uma imagem subjetiva de Deus e, por meio de tal, afirmem a sua profissão de fé. No entanto, quando a 
representação subjetiva é representada como um objeto fenomênico, ela se torna uma ilusão religiosa. A ilusão religiosa é o

[...] engano que consiste em ter a simples representação de uma coisa por equivalente à própria coisa. [...] A própria demência (Wahnsinn) tem este nome porque costuma tomar uma simples representação (da imaginação) pela presença da própria coisa, e também apreciá-la. ( $R G V, \mathrm{AA}, 06,203)^{24}$.

A ilusão tem um papel crucial na demência (Wahnsinn), ela considera uma simples representação da imaginação como a presença do próprio objeto, isto é, estabelece uma confusão entre os conceitos puros e as sensaçóes. Kant caracteriza a demência (Wahnsinn) como uma simples representação da imaginação, ou seja, a imaginaçáo na falta do objeto representa-o como se ele estivesse presente na sensação. Kant afirma que faculdade da imaginação reprodutiva é a faculdade responsável em trazer, ao espírito, intuiçôes já experimentadas pela sensibilidade. Já a capacidade fantasiosa da imaginação é a ficção de fazer livre associação entre as imagens da faculdade da imaginação reprodutiva, assim, transformando uma intuição fantasiosa em um tipo de conhecimento empírico.

Na perspectiva de Kant, não é ruim que o homem forje para si uma imagem subjetiva de Deus, por meio de conceitos morais, mas ele não poderá representá-la como um objeto fenomênico. O homem deve pensar na existência de Deus como ser moral relacionando-o com a sua vontade e o mundo. Na $R G V$ há dois modos de representar a imagem subjetiva de Deus, a saber, por meio de um antropomorfismo dogmático (dogmatischen Anthropomorphismus) ou por meio de um antropomorfismo simbólico (symbolischen Anthropomorphism). Sobre o antropomorfismo dogmático e simbólico, Kant escreve:

Com efeito, não atribuímos então ao ser supremo nenhuma das propriedades pelas quais pensamos objetos da experiência e evitamos assim o antropomorfismo dogmático; atribuímos, contudo, estas propriedades à sua relação com o mundo e permitimos um antropomorfismo simbólico que, na realidade, apenas concerne à linguagem e não ao próprio objeto ( Prol, AA, $04 / \mathrm{A}, 176)^{25}$.

24 Wahn ist die Täuschung, die bloße Vorstellung einer Sache mit der Sache selbst für gleichgeltend zu halten.[...] Selbst der Wahnsinn hat daher diesen Namen, weil er eine bloße Vorstellung (der Einbildungskraft) für die Gegenwart der Sache selbst zu nehmen, und eben so zu würdigen gewohnt ist.

25 Denn alsdenn eignen wir dem höchsten Wesen keine von den Eigenschaften an sich selbst zu, durch die wir uns Gegenstände der Erfahrung denken, und vermeiden dadurch den dogmatischen Anthropomorphismus, wir legen sie aber dennoch dem Verhältnisse desselben zur Welt bei, und erlauben uns einen symbolischen 
Kant, no Prol, define o antropomorfismo simbólico como o "conhecimento por analogia, que não significa como a palavra se entende comumente, uma semelhança imperfeita entre as duas coisas, mas uma semelhança perfeita de duas relaçóes entre coisas inteiramente dessemelhantes" (Prol, AA, 04/A, 176) ${ }^{26}$. Em outras palavras, o antropomorfismo simbólico considera duas coisas totalmente dessemelhantes, por exemplo, a vontade do ser racional finito e Deus, relacionadas em perfeita harmonia. Na relação analógica que o ser racional finito faz de Deus e a sua vontade, deve ser mediada pela lei moral. Logo, a representaçáo de Deus se dá na forma de um ser moral, que age sobre a vontade do ser racional finito. Se a ideia da existência de Deus for reproduzida pela sensibilidade, ela perde o estatuto de juízo da fé e passa a ser um juízo determinante. No juízo determinante, o conceito subsumido se assenta sobre intuiçóes sensíveis, estabelecendo uma realidade para um conceito dada uma lei do entendimento. Os juízo da fé, diferente dos juízos determinantes, tem que subsumir sob um princípio interno que não tem validade objetiva, assim, constituindo um princípio para a reflexão sobre objetos da razão prática. Para localizar o problema do estatuto do juízo da fé, encontramos a seguinte citação na $R G V$ :

Tal é o esquematismo da analogia (symbolischen Anthropomorphism) (para a explicação) de que não podemos prescindir. Mas transformá-lo nem esquematismo da determinação do objeto (dogmatischen Anthropomorphismus) (para a ampliação do nosso conhecimento) é antropomorfismo, que num propósito moral (na religião) tem as mais prejudiciais consequências.

Quero apenas observar de passagem que, na ascensáo do sensível para o suprassensível, se pode decerto esquematizar (fazer apreensível um conceito por meio da analogia com algo de sensível), mas de nenhum modo se pode inferir, de acordo com a analogia, sobre o que pertence ao sensível que ele deva atribuir-se igualmente ao suprassensível (e alargar assim o seu conceito); isto, sem dúvida, pela razão inteiramente simples de que iria contra toda a analogia semelhante raciocínio, o qual, em virtude de usarmos necessariamente um esquema para um conceito a fim de no-lo tornar compreensível (documentá-lo mediante um exemplo), quereria tirar a consequência de que ele há de por força corresponder ao próprio objeto, como seu predicado. Não posso dizer: assim como não consigo tornar para mim apreensível a causa de uma planta (ou de toda a criatura orgânica e, em geral, do mundo repleto de finalidade) de nenhum outro modo a náo ser segundo a analogia de um artista em relação à sua obra (um relógio), a saber, atribuindo-lhe entendimento, assim também a própria causa (da planta, do mundo em geral) há de ter entendimento, ou seja, atribuir-lhe entendimento não é apenas uma condição da minha

Anthropomorphism, der in der Tat nur die Sprache und nicht das Objekt selbst angeht.

26 Eine solche Erkenntnis ist die nach der Analogie, welche nicht etwa, wie man das Wort gemeiniglich nimmt, eine unvollkommene Ähnlichkeit zweener Dinge, sondern eine vollkommne Ähnlichkeit zweener Verhältnisse zwischen ganz unähnlichen Dingen bedeutet. 
apreensibilidade, mas da própria possibilidade de ser causa. Entre a relação de um esquema ao seu conceito e a relação deste esquema à própria coisa nâo há qualquer

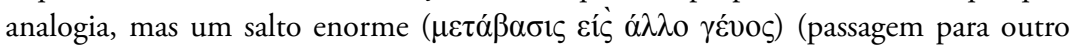
gênero), que conduz diretamente ao antropomorfismo, de que já forneci as provas noutro lugar $\left(R G V\right.$, AA, 06, 76) ${ }^{27}$.

$\mathrm{Na} R G V$, a imagem subjetiva de Deus é forjada por meio do antropomorfismo simbólico e não do dogmático, pois o ser racional finito pensa a existência de Deus em relação à sua vontade e o mundo. Em outras palavras, representar a imagem subjetiva de Deus como algo efetivo no mundo fenomênico, na perspectiva kantiana, é um tipo de fanatismo religioso. O fanatismo religioso é um erro sub-reptício, ou seja, uma confusão entre os conceitos puros e as sensações na formulação do juízo. Entre o esquematismo da analogia (Schematism der Analogie) e o esquematismo da determinação do objeto (Schematism der Objektsbestimmung) há uma diferença na elaboração dos seus resultados, o primeiro torna apreensivel (faßlich) um conceito suprassensível, enquanto o segundo permite alagar um conceito (Begriff erweitern) por intermédio de um conceito suprassensível.

Tornar um conceito apreensível (faßlich) é conhecer o desconhecido por intermédio do conhecido. Isto significa que nós não podemos conhecer a natureza divina, mas apreendemos a natureza divina por intermédio da nossa vontade. A vontade do ser racional finito é determinada pela lei moral. A lei moral manda incondicionalmente sobre a vontade do homem regida por leis da liberdade. Ao relacionarmos a ideia da existência de Deus com a vontade do

27 Das ist der Schematism der Analogie (zur Erläuterung), den wir nicht entbehren können. Diesen aber in einen Schematism der Objektsbestimmung (zur Erweiterung unseres Erkenntnisses) zu verwandeln ist Anthropomorphism, der in moralischer Absicht (in der Religion) von den nachteiligsten Folgen ist.

Hier will ich nur noch beiläufig anmerken, daß man im Aufsteigen vom Sinnlichen nun Übersinnlichen zwar wohl schematisieren (einen Begriff durch Analogie mit etwas Sinnlichem faßlich machen), schlechterdings aber nicht nach der Analogie von dem, was dem ersteren zukömmt, daß es auch dem letzteren beigelegt werden müsse, schließen (und so seinen Begriff erweitern) könne, und dieses zwar aus dem ganz einfachen Grunde, weil ein solcher Schluß wider alle Analogie laufen würde, der daraus, weil wir ein Schema zu einem Begriffe, um ihn uns verständlich zu machen (durch ein Beispiel zu belegen), notwendig brauchen, die Folge ziehen wollte, daß es auch notwendig dem Gegenstande selbst, als sein Prädikat zukommen müsse. Ich kann nämlich nicht sagen: so wie ich mir die Ursache einer Pflanze (oder jedes organischen Geschöpfs und überhaupt der zweckvollen Welt) nicht anders faßlich machen kann, als nach der Analogie eines Künstlers in Beziehung auf sein Werk (eine Uhr), nämlich dadurch, daß ich ihr Verstand beilege: so muß auch die Ursache selbst (der Pflanze, der Welt überhaupt) Verstand haben; d.i. ihr Verstand beizulegen ist nicht bloß eine Bedingung meiner Faßlichkeit, sondern der Möglichkeit Ursache zu sein selbst. Zwischen dem Verhältnisse aber eines Schema zu seinem Begriffe und dem Verhältnisse eben dieses Schema des Begriffs zur Sache selbst ist gar keine Analogie, sondern ein gewaltiger Sprung (metabasis eis allo genos), der gerade in den Anthropomorphism hinein führt, wovon ich die Beweise anderwärts gegeben habe. 
ser racional finito, estamos também relacionando a ideia do ser supremo com a lei moral. $\mathrm{O}$ que conhecemos da ideia da existência de Deus é apreensível (faßlich) da tríplice relação: vontade, Deus e lei moral. A lei moral possibilita fazer a relação entre Deus e a vontade, e torna apreensível (faßlich) a ideia de Deus como ser moral. Portanto, a função do esquematismo da analogia (Schematism der Analogie) é tornar um conceito apreensível (faßlich), na razão prática como legislador moral e na razão teórica como criador do mundo.

O esquematismo da analogia opera por intermédio do princípio de razão suficiente, que exige que para todo efeito haja uma causa determinável. Como exemplo, Kant argumenta da mesma forma que é necessário pensar o relógio como criado pelo relojoeiro, também é necessário pensar o mundo como criado por Deus. Nesta relaçáo entre causa e efeito náo estamos concluindo que a natureza de Deus é criadora, mas que podemos apreender a sua existência como criador do mundo. No esquematismo de analogia (Schematism der Analogie), Deus existe como possibilidade do fundamento do pensar, pensar uma causa para a existência do mundo. Mas não podemos concluir da existência de Deus a existência do mundo, pois não podemos avançar nesse tipo de conhecimento. Dito noutras palavras, náo podemos alargar um conceito (Begriff erweitern) suprassensível, assim avançando no conhecimento teórico, apenas podemos relacioná-lo com objetos sensíveis.

A diferença entre alargar um conceito (Begriff erweitern) ou torná-lo apreensível (faßlich) é que no esquematismo determinante de um objeto (Schematism der Objektsbestimmung) afirmamos o que é a natureza divina. E no esquematismo de analogia (Schematism der Analogie) afirmamos o significado da natureza divina como ser moral ou criador do mundo. O primeiro ultrapassa a pedra de toque da razáo, ou seja, considera um conceito intelectual como um conceito sensível, assim excedendo o limite do que podemos conhecer. O segundo torna apreensível um conceito suprassensível por intermédio de analogia, a função do esquematismo de analogia é apenas explicativa e náo possibilita alargar o conceito que temos da ideia ou do postulado.

Kant, na $R G V$, afirma já ter dado prova sobre o conhecimento analógico noutra obra. No Prol, Kant escreve: 
entendimento e de uma vontade suprema, apenas digo, na realidade: assim como um relógio, um barco, um regimento se refere ao relojoeiro, ao construtor e o coronel, assim também o mundo sensível se refere ao desconhecido que eu, pois, não descubro segundo o que ele é em si mesmo, mas segundo o que ele é para mim, a saber, em consideraçáo ao mundo do qual eu sou parte (Prol, AA, 04 / A, 176) ${ }^{28}$.

Ao afirmarmos a existência de Deus por intermédio da vontade do ser racional não estamos transferindo predicados do mundo sensível para o mundo suprassensível. Ao contrário, estamos pensando na existência de Deus como nós o imaginamos, como ser moral, assim, conhecemos o desconhecido pelo conhecido. A hipótese transcendental e o postulado da existência de Deus possibilitam ao ser racional finito pensar numa causa criadora do mundo e na ideia de um legislador moral, assim, o ser racional finito relaciona a ideia da existência de Deus e com o mundo e com a vontade. Agora, afirmar a existência de Deus por intermédio de um juízo determinante é atribuir uma intuição ao conceito puro. Isto significa determinar a sensibilidade como a origem dos conceitos puros.

\section{A origem dos conceitos puros}

Segundo Mayr (Cf. 2008, p. 31), nos séculos XVII-XVIII, havia um embate entre a teoria da pré-formaçáo e a teoria da epigênese, que dominou as discussóes sobre a biologia na Alemanha. Kant se posiciona ante ao debate defendendo a teoria da epigênese. Para Mayr, o embate entre a teoria da pré-formação e a teoria da epigênese é definido nos respectivos termos: "os pré-formacionistas sustentavam que as partes que compóem um adulto existem numa forma menor desde o começo do desenvolvimento. Os epigenesistas defendiam que as partes do adulto aparecem como produtos do desenvolvimento, mas não estáo presentes como parte no começo" (MAYR, 2008, p. 31). Noutras palavras, os defensores da teoria da préformação afirmam que dentro do primeiro ser de cada espécie já está contido todos os seres daquela espécie e, além disso, também afirmam que todas as características que compóem um adulto já estão presentes no embrião, desde seu nascimento. Por outro lado, os defensores da

28 Wenn ich sage, wir sind genötigt, die Welt so anzusehen, als ob sie das Werk eines höchsten Verstandes und Willens sei, so sage ich wirklich nichts mehr, als: wie sich verhält eine Uhr, ein Schiff, ein Regiment, zum Künstler, Baumeister, Befehlshaber, so die Sinnenwelt (oder alles das, was die Grundlage dieses Inbegriffs von Erscheinungen ausmacht) zu dem Unbekannten, das ich also hiedurch zwar nicht nach dem, was es an sich selbst ist, aber doch nach dem, was es vor mich ist, nämlich in Ansehung der Welt, davon ich ein Teil bin, erkenne. 
epigênese afirmam que as características biológicas são produtos do próprio desenvolvimento do ser vivo, que não necessariamente estão presente desde o princípio.

$\mathrm{Na} K r V$, no final da Doutrina Transcendental, mais especificamente na Lógica Transcendental, Kant assevera que há "duas vias pelas quais poder ser pensada a necessária concordância da experiência com os conceitos ou são esses conceitos que possibilitam a experiencia" ( $K r V, \mathrm{~B}, 167)$. O dilema apresentado objetiva elucidar a sentença de que: "náo podemos pensar nenhum objeto que não seja por meio de categorias; não podemos conhecer nenhum objeto pensado a não ser por intuiçóes correspondentes a esses conceitos" ( $K r V$, B, 167). Para Kant, as categorias do entendimento são as condiçôes necessárias para se pensar o objeto, esta condição é dada a priori e não tem nenhuma influência da experiência. Destarte, toda intuição é sensível e pertence ao domínio do conhecimento empírico na medida em que o objeto é dado. Todavia, "nenhum conhecimento a priori nos é possível, a não ser o de objetos de uma experiência possível” $(K r V, \mathrm{~B}, 166)$. Referente à última afirmação sobre o conhecimento a priori, é necessário ressaltar que as categorias não são limitadas pelas condiçóes da nossa intuição, pelo contrário, são ilimitadas. As categorias só são limitadas pela nossa intuição naquilo que conhecemos de determinada objeto sensível. Assim, tornando-se necessária a concordância entre as categorias e as intuiçóes, isto é, dos conceitos com a experiência.

O problema da concordância dos conceitos com a experiência surge no momento de determinar se é a experiência que concorda com os conceitos ou se são os conceitos que possibilitam a experiência. Referente ao problema, Kant escreveu:

$\mathrm{O}$ primeiro caso não se verifica em relação às categorias (nem mesmos em relação à intuição sensível pura), porque as categorias são conceitos a priori, portanto, independentes da experiência (a afirmação de uma origem empírica seria uma espécie de generatio aequivoca). Resta-nos, por conseguinte, apenas o segundo caso (por assim dizer um sistema de epigênese da razáo pura), ou seja, que as categorias contêm, do lado do entendimento, os princípios da possibilidade de toda experiencia em geral $(K r V, \mathrm{~B}, 167)^{29}$.

\footnotetext{
${ }^{29}$ Das erstere findet nicht in Ansehung der Kategorien (auch nicht der reinen sinnlichen Anschauung) statt; denn sie sind Begriffe a priori, mithin unabhängig von der Erfahrung (die Behauptung eines empirischen Ursprungs wäre eine Art von generatio aequivoca). Folglich bleibt nur das zweite übrig (gleichsam ein System der Epigenesis der reinen Vernunft): daß nämlich die Kategorien von Seiten des Verstandes die Gründe der Möglichkeit aller Erfahrung überhaupt enthalten.
} 


\title{
O próprio Kant elimina a primeira opção, da concordância da experiência com os
} conceitos, as categorias do entendimento são independentes da experiência. Logo, a solução do problema é: os conceitos possibilitam a experiência. Kant exclui a opção de a experiência possibilitar os conceitos devido à incoerência de uma generatio aequievoca (geração espontânea). $\mathrm{Na}$ perspectiva kantiana, a experiência não pode gerar espontaneamente as categorias, pois elas estariam limitadas totalmente pela experiência, assim, restringindo o pensar aos objetos existentes. Noutras palavras, pensar e conhecer se tornariam conceitos equivalentes. Por isso, na disjunção sobre a concordância entre os conceitos e a experiência está excluída a assertiva: a experiência possibilita os conceitos.

Para explicar como é possível os conceitos possibilitarem a experiência, Kant recorre à teoria da epigênese e assevera:

\begin{abstract}
se entre os dois únicos caminhos mencionados alguém quisesse propor uma via intermédia, em que as categorias não fossem nem primeiro princípios a priori, espontaneamente pensados, do nosso conhecimento, nem também extraídos da experiência, nas disposiçôes subjetivas para pensar, implantadas em nós conjuntamente com a nossa existência, de tal modo dispostas pelo nosso Criador que o seu uso coincidiria, rigorosamente, com as leis da natureza, segundo as quais se vai desenvolvendo a experiência (uma espécie de sistema da preformação da razão pura), é fácil refutar esse sistema: o que seria decisivamente contrário a via intermédia em questão (além de eu em semelhante hipótese não se vê onde tenhamos de pôr termo a essa suposição de disposiçóes predeterminadas para juízos futuros), faltaria às categorias a necessidade, que essencialmente pertence ao seu conceito $(K r V, \mathrm{~B}, 168)^{30}$.
\end{abstract}

Se pensarmos uma via intermédia entre a concordância dos conceitos com a experiência é necessário considerar a possibilidade de disposiçóes predeterminadas, presentes na natureza humana. Estas disposições predeterminadas seriam implantadas em nós por Deus, no início de nossa existência. Logo, não se pode estabelecer a relação entre causa e efeito na relação entre os conceitos e a experiência. Isto quer dizer, não se pode afirmar que: a experiência possibilita os conceitos ou que os conceitos possibilitam a experiência, porque é inviável estabelecer a relação de

\footnotetext{
${ }^{30}$ Wollte jemand zwischen den zwei genannten einzigen Wegen noch einen Mittelweg vorschlagen, nämlich, daß sie weder selbstgedachte erste Prinzipien a priori unserer Erkenntnis, noch auch aus der Erfahrung geschöpft, sondern subjektive, uns mit unserer Existenz zugleich eingepflanzte Anlagen zum Denken wären, die von unserm Urheber so eingerichtet worden, daß ihr Gebrauch mit den Gesetzen der Natur, an welchen die Erfahrung fortläuft, genau stimmte (eine Art von Präformationssystem der reinen Vernunft), so würde (außer dem, daß bei einer solchen Hypothese kein Ende abzusehen ist, wie weit man die Voraussetzung vorbestimmter Anlagen zu künftigen Urteilen treiben möchte) das wider gedachten Mittelweg entscheidend sein: daß in solchem Falle den Kategorien die Notwendigkeit mangeln würde, die ihrem Begriffe wesentlich angehört.
} 
necessidade entre o conceito e a experiência ou vice-versa. Para validar o argumento, Kant recorre ao princípio do terceiro excluído. $\mathrm{Na}$ disjunção, é a experiência que possibilita os conceitos ou são os conceitos que possibilitam a experiência, tanto a experiência é pensada como causa necessária para os conceitos, quanto os conceitos são pensados como causa necessária para a experiência. Logo, um dos lados deve ser verdadeiro, porque há uma relação de necessidade. Em linhas gerais, são os conceitos que possibilitam a experiência, uma vez que não são limitados pela experiência na capacidade de pensar, mas são limitados pela experiência naquilo que podemos conhecer de determinado objeto sensível.

Para demonstrar a invalidade da posição intermediária entre a concordância do conceito com a experiência, pode-se utilizar a redução ao absurdo. Em qualquer um dos lados da disjunção, "há só duas vias pelas quais pode ser pensada a necessária concordância da experiência com os conceitos dos seus objetos: é a experiência que possibilita esses conceitos ou são esses conceitos que possibilitam a experiência” ( $K r V, \mathrm{~B}, 167)$, o efeito está ligado à causa no objeto, ou seja, necessariamente. Se pensarmos a conformidade entre o conceito e a experiência pela via intermediária apenas podemos asseverar que:

sou de tal modo constituído que não posso pensar esta representação de outro modo que não seja ligada desta maneira; eis o que o cético mais deseja, porque assim todo o nosso saber, fundado na pretensa validade objetiva dos nossos juízos, náo seria mais do que pura aparência e não faltaria quem por si negasse essa necessidade subjetiva (que deve ser sentida); náo se poderia pelo menos argumentar com ninguém sobre aquilo que assenta apenas no modo pelo qual está organizado como sujeito $(K r V, \mathrm{~B}, 168)^{31}$.

O conceito de causa que exige a necessidade de uma consequência para uma condiçáo pressuposta é impossível, porque agiremos motivados por disposiçöes predeterminadas para juízos futuros. Dito de outro modo, pensaríamos analogamente às leis da natureza, logo, não poderíamos pensar de outro modo senão segundo a regra da lei divina colocada em nós. A concordância entre os conceitos e a experiência náo estaria no esclarecimento se os conceitos fossem causas da experiência ou se a experiência fosse causa dos conceitos, mas na disposição

\footnotetext{
${ }^{31}$ ich bin nur so eingerichtet, daß ich diese Vorstellung nicht anders als so verknüpft denken kann; welches gerade das ist, was der Skeptiker am meisten wünscht; denn alsdenn ist alle unsere Einsicht, durch vermeinte objektive Gültigkeit unserer Urteile, nichts als lauter Schein, und es würde auch an Leuten nicht fehlen, die diese subjektive Notwendigkeit (die gefühlt werden muß) von sich nicht gestehen würden; zum wenigsten könnte man mit niemanden über dasjenige hadern, was bloß auf der Art beruht, wie sein Subjekt organisiert ist.
} 
colocada pelo Criador na natureza humana. A posiçáo intermediária, na perspectiva kantiana, inviabiliza pensar a concordância necessária entre os conceitos com a experiência, estipulando um causa hiperfísica. Se considerarmos o argumento da causa hiperfísica, podemos estruturá-lo do seguinte modo:

\section{Premissa maior Deus é a causa da concordância entre os conceitos e a experiência. Premissa menor O Ser humano pensa e conhece conforme esta concordância. Conclusáo Logo, Deus é a causa do pensar e do conhecer humano.}

Se tivermos como hipótese a sentença Deus é a causa do pensar humano, o homem não poderá pensar ou conhecer diferentemente da maneira como foi impressa por Deus. Assim, resta, apenas, para ele afirmar: "sou de tal modo constituído que náo posso pensar esta representação de outro modo que não seja ligada desta maneira [...]" (KrV, B, 168). Assim, tornando impossível pensar necessariamente a concordância entre o conceito e a experiência, porque pensar e conhecer se tornam conceitos equivalentes. A posiçáo intermediária da disjunção da concordância entre os conceitos e a experiência assevera que Deus predetermina o pensar e o conhecer humano, assim, o homem não pode pensar e conhecer de outro jeito senão daquele que Deus predeterminou. Kant alinha a posição intermediária com a teoria da preformação. Esta afirma que as disposições que compóem a natureza humana estáo presentes desde o começo, como algo colocado pelo Criador, que é transmitido de geração em geraçáo, sem sofrer nenhuma alteraçáo. Assim, a teoria da epigênese defende que as disposiçóes aparecem como resultado do desenvolvimento do próprio ser vivo e não como manifestaçáo de

algo simplesmente colocado pelo Criador na natureza humana. Noutras palavras, utilizando o jargão kantiano, o próprio funcionamento da faculdade do entendimento exige as categorias como causa necessária para o seu próprio funcionamento, deste modo, os conceitos possibilitam a experiência necessariamente.

Se Deus é a causa da concordância entre os conceitos e a experiência, entáo, o ser humano pensa e conhece conforme esta concordância. Neste juízo, o condicionado valida a condição, se negarmos o condicional negamos a condição. O condicional é o modo como o ser humano conhece e pensa e a condiçáo é atribuir a Deus o modo como o ser humano pensa, 
assim, Deus é a causa da concordância entre os conceitos e a experiência. Ou seja, se negarmos o condicional, negamos a condição. Figura silogística (Tollendo tollens):

\section{Se P, então Q. \\ - Q. \\ Portanto, - P.}

Contudo, é extremamente necessário pensarmos a concordância entre os conceitos e a experiência. Se construirmos um silogismo disjuntivo da posição intermediária, ele seria enunciado do seguinte modo: a concordância entre os conceitos e a experiência náo tem causa ou Deus é a causa dessa concordância. Uma disjunção só é verdadeira, se um dos disjuntivos é falso, assim, o outro é necessariamente verdadeiro.

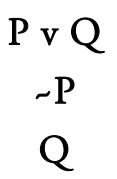

No silogismo disjuntivo um dos lados deve ser falso para o outro ser verdadeiro. A validade do argumento se fundamenta na necessidade lógica de uma das proposiçóes serem verdadeiras. Na perspectiva de Kant, o argumento intermediário é contraditório, porque inviabiliza a relação de necessidade entre os conceitos e a experiência e, além disso, o ser racional finito apenas pode afirmar que é constituído de determinado modo que não pode pensar de outro jeito, senáo aquele determinado pela lei divina. Este argumento é contraditório, segundo Kant, uma vez que afirma: Deus predetermina o pensar e o conhecer através de disposiçóes predeterminadas presentes na natureza humana. A teoria da preformação gera um argumento circular que náo estipula a relação de necessidade entre os conceitos e a experiência. Deste modo, antes de conhecer poderíamos pensar e antes de pensar poderíamos conhecer, pois não há relação de necessidade entre os conceitos e a experiência. Portanto, só asseveraríamos que pensamos e conhecemos de tal modo que não podemos pensar e conhecer de outro modo. Por fim, as noçôes de pensar e conhecer se tornam auto contraditórias.

Se considerarmos a teoria da preformação como explicaçáo da concordância entre os conceitos puros do entendimento e a experiência, teríamos que fundamentar esta relação numa 
causa sobrenatural. Mas se considerarmos a existência de um sistema da epigêneses da razão pura (System der Epigenesis der reinen Vernunft) estaremos asseverando que é a razão pura que realiza o processo da epigêneses. Dito de outro modo, a teoria da epigênese pressupóe uma causa inferida do efeito, sendo a causa um produto do próprio desenvolvimento da razão. O próprio modo de operação da razão é a causa dos conceitos puros do entendimento, que possibilita estabelecer uma relação de necessidade entre os conceitos e a experiência e a distinção entre pensar e conhecer. Concluindo, as causas são inferidas do próprio efeito como consequência do próprio modo de operação da razáo. Desse modo, Kant restringe o princípio de causalidade ao modo de funcionamento da razão e não atribui para efeitos (orgânicos) causas sobrenaturais.

\section{CONSIDERAÇÓES FINAIS}

Kant, na $R G V$, afirma já ter dado prova sobre o conhecimento analógico noutra obra. No Prol, Kant escreve:

[...] somos forçados a considerar o mundo como se ele fosse a obra de um entendimento e de uma vontade suprema, apenas digo, na realidade: assim como um relógio, um barco, um regimento se refere ao relojoeiro, ao construtor e o coronel, assim também o mundo sensível se refere ao desconhecido que eu, pois, não descubro segundo o que ele é em si mesmo, mas segundo o que ele é para mim, a saber, em consideração ao mundo do qual eu sou parte (AA 04 Prol A176) ${ }^{32}$.

Ao afirmarmos a existência de Deus por intermédio da vontade do ser racional não estamos transferindo predicados do mundo sensível para o mundo supra-sensível. Ao contrário, estamos pensando na existência Deus como nós o imaginamos como ser moral, assim, conhecemos o desconhecido pelo conhecido. A hipótese transcendental e o postulado da existência de Deus possibilitam ao ser racional finito pensar numa causa criadora do mundo e na ideia de um legislador moral, assim, o ser racional finito relaciona a ideia da existência de Deus com o mundo e com a vontade. Agora, afirmar a existência de Deus por intermédio de

${ }^{32}$ Wenn ich sage, wir sind genötigt, die Welt so anzusehen, als ob sie das Werk eines höchsten Verstandes und Willens sei, so sage ich wirklich nichts mehr, als: wie sich verhält eine Uhr, ein Schiff, ein Regiment, zum Künstler, Baumeister, Befehlshaber, so die Sinnenwelt (oder alles das, was die Grundlage dieses Inbegriffs von Erscheinungen ausmacht) zu dem Unbekannten, das ich also hiedurch zwar nicht nach dem, was es an sich selbst ist, aber doch nach dem, was es vor mich ist, nämlich in Ansehung der Welt, davon ich ein Teil bin, erkenne. 
um juízo determinante é atribuir uma intuição ao conceito puro. Isto significa determinar a sensibilidade como a origem dos conceitos puros.

\section{Referências Bibliográficas:}

ALLISON, Henry E. Kant's theory of freedom. Cambridge, England: Cambridge University Press, 1995.

BECK, L. W. A commentary on Kant's Critique of Practical Reason. Chicado: University Of Chigado Press, 1960.

HENRICH, D. Aesthetic Judgment and the moral Image of the World. Stanford University Press. 1992.

Kant, Immanuel: Gesammelte Schriften Hrsg.: Bd. 1-22 Preussische Akademie der Wissenschaften, Bd. 23 Deutsche Akademie der Wissenschaften zu Berlin, ab Bd. 24 Akademie der Wissenschaften zu Göttingen. Berlin 1900ff.

$A A \quad$ Akademie-Ausgabe

Anth Anthropologie in pragmatischer Hinsicht (AA 07)

GMS Grundlegung zur Metaphysik der Sitten (AA 04)

Kp $\quad$ Kritik der praktischen Vernunft (AA 05)

$\mathrm{KrV} \quad$ Kritik der reinen Vernunft (zu zitieren nach Originalpaginierung A/B)

KU Kritik der Urteilskraft (AA 05)

Log $\quad$ Logik (AA 09)

Prol Prolegomena zu einer jeden künftigen Metaphysik (AA 04)

$R G V \quad$ Die Religion innerhalb der Grenzen der bloßen Vernunft (AA 06)

SF $\quad$ Der Streit der Fakultäten (AA 07)

KANT, I. Crítica da razão pura. Trad. Valério Rohden e Udo Baldur Moosburger. São Paulo: Abril, 1980.

. Crítica da razão prática. Ed. Bilíngüe. Trad. Valério Rohden. São Paulo: Martins Fontes, 2003.

- Crítica da Faculdade do Juizo. 2a Ed. Trad. Valério Rohden e António Marques. Rio de Janeiro: Forense Universidade, 2005. 
. Prolegômenos a toda a metafísica futura. Trad. Artur Morão. Lisboa/Portugal:

Edições 70, 2003.

. O conflito das Faculdades. Trad. Artur Morão. Lisboa/Portugal: Edições 70, 1993.

- A religião nos limites da simples razão. Trad. Lisboa/Portugal: Ediçóes 70, 1993.

OSTARIC, L. Genius and the "Moral Image of the World". In VALÉRIO, Rodhen. Recht und Frieden in der Philosophie Kants. Berlin - New York: Wlater de Gruyter, 2009.

. Works of Genius as Sensible Exhibitions of the Idea of the Highest Good. KantStudien. Volume 101, Issue 1, Pages 22-39, ISSN 0022-8877. March/2010.

RAUSCHER, Frederick. God Without God: Kants Postulate as a Useful Extensionless Concept. Kant e-prints. Campinas, Série 2, v. 2, n2. p. 73-91, jul-dez. 2007 